\title{
Youth Participation in Agriculture in the Nkonkobe District Municipality, South Africa
}

\author{
Priviledge Cheteni \\ Department of Agricultural Economics and Extension, Faculty of Science and Agriculture, \\ University of Fort Hare (Alice Campus), PBX1314, Alice 5700, South Africa \\ E-mail: 200909553@ufh.ac.za
}

KEYWORDS Binary Model. New Growth Plan. Perception. Rural Development. Youth Participation

\begin{abstract}
In this paper, a binary logistic model was used to analyse the determinants of youth participation in agriculture in the Nkonkobe Municipality in South Africa. A total of 140 youth were purposively selected for the study to complete a survey. The results show that the variables; youth programmes, programme availability, and resources were statistically significant in explaining the factors that affect youth participation in agricultural activities. Based on the study findings, it is recommended that in order to influence youth participation, they should be provided with youth programmes and resources.
\end{abstract}

\section{INTRODUCTION}

Since 1994 the South Africa economy has passed through a number of economic, social and political phases. The country has been integrated into the global system, and progressing well in trying to address injustices that occurred during the apartheid era (DAFF 2014). Under the apartheid era, blacks were subjected to impoverished living conditions under the white minority. The situation was exacerbated in agriculture were black smallholder farmers' productivity was affected. However, in the late 1970s and onwards the South African government prioritised agriculture (Tregurtha et al. 2008). Although, agriculture was prioritised, smallholder farmers were still sidelined in benefiting from a number of agricultural initiatives (DAFF 2014). Post-1994 saw the government reprioritising agriculture in order to support black emerging farmers. In 2001, a Land Redistribution programme was launched to return part of the land taken during apartheid to black farmers. A special emphasis was made in the inclusion of women and youth in the programme (DAFF 2012). Apart from this, a number of initiatives like the Reconstruction and Development Programme (RDP), Accelerated and Shared Growth Initiative and Growth (AsgiSA), Employment Redistribution Strategy (GEAR) were launched in order to address a number of problems like unemployment, inequality and economic growth. However, one of the striking features within government policies or frameworks is the continuous interest in the upliftment of the standard of living of blacks, reducing inequality and unemployment (DAFF 2013). Furthermore, youth have emerged in recent debates as a priority to the government.

There is a widespread belief that youth play a vital role in agricultural and rural development (Ommani et al. 2006). The New Growth Path (NGP) policy which was launched in 2011 seeks to create employment mainly for the youth. Therefore, the government interest in youth is well supported by FAO (2011) which noted that the youth were the most disadvantaged group. Thus, youth participation in agriculture presents the nation with an opportunity to expand the agricultural sector. However, of late youth involvement in agriculture has been declining nationally, especially in the rural areas (Russel 2001). Therefore, this lack of participation has led to an exodus of youth migrating to urban areas. This situation is further fuelled by the attitude of rural youth pertaining agricultural activities and their inclination to pseudo jobs (Ghadiri 2005). Omani (2006) noted that job security and good living conditions attract the youth to urban areas. Similarly, lack of education means that the youth cannot gain formal employment; hence, migration to the cities to partake in informal small-scale enterprises remains preferable to farming (TeLintelo 2001). Woolard (2013) noted that most youth in South Africa were migrating to urban areas to look for jobs, partly due to the low status attached to farming and lack of growth in career. This migration increases problems in urban areas by leading to overcrowded cities, inequitable distribu- 
tion of resource and a heavy load for those remaining in agriculture (Mathivah 2012). Apart from the challenges encountered by youth, such as, poverty and low income, youth have a low self-esteem (Samardick et al. 2000). The low selfesteem associated with youth increases the negative perception they have about agriculture, leading to non-participation. Similarly, Outley (2008) posits that perception and social status act as barriers to youth pursuing careers in agriculture, as well as, lack of information. Such perceptions are said to have an influence on the participation in agriculture leading to some groups being underrepresented.

Despite the enormous contribution of youth to household agriculture, only a few empirical studies (Nnadi et al. 2008; Naamwintome et al. 2013, Kimaro et al. 2015; Anania et al. 2016) have tried to identify factors affecting the youth participation in agricultural activities. These studies highlight that socio-economic factors influence youth participation in agriculture, although they do not provide an analysis of other exogenous factors, which hinder youth participation in agriculture. Therefore, this study shifts the focus from socio-economic factors to exogenous factors that have a bearing on youth participation in agriculture based on anecdotal evidence. In the process closing the literature gap, that exists in youth participation studies.

\section{Objective}

The primary objective of this study was to assess factors influencing the participation of youth in Agriculture in Nkonkobe District Municipality in the Eastern Cape Province, South Africa. For the purposes of this study, a youth is defined as an individual within the age range of 18 to 35 years (United Nations 1999).

\section{MATERIAL AND METHODS}

The study was conducted in Alice and Seymour in the Nkonkobe Municipality, Eastern Cape Province of South Africa. The estimated population in Nkonkobe Municipality is 1,27,117 with total households 35,355 (Stats SA 2011). Nkonkobe local Municipality falls under the Amatole District Municipality, which has seven local municipalities namely: Ngqushwa, Great Kei, Mnquma, Mbhashe, Nkonkobe and Amahlathi. The average household income per year is
ZAR42764 and household size is 3.5 (Stats SA 2011). Primary data were collected with a semistructured questionnaire that was pretested before the survey. A cross-sectional study design was used to collect data from households, whereby youth were the targeted respondents. The questionnaire was structured into four parts whereby information related to demographics, farm characteristics, participation, and perception towards agriculture were collected. Five enumerators were trained to interview the respondents. A total of 140 youth were purposively sampled. The main reason for choosing this method was to include the relevant respondents. The data gathered were coded and analysed using the SPSS Software. Since the study was more descriptive in nature, percentages and chi square tests were calculated to reveal the general information of respondents. Multi-collinearity tests were done to check if the data was suitable for a binary choice model. Normality tests were also done by testing skewness and the data was normal. A binary logistic model was applied to analyse factors influencing participation of youth in agriculture.

The binary regression model was used to test the influence of the hypothesised explanatory factors on the dependent variable. It takes the following form:

In $(\mathrm{ODDS})=\operatorname{In}(\mathrm{p} / 1-\mathrm{P})=\beta 0+\beta 1 \mathrm{X} 1+\ldots+\beta \mathrm{nXn} . .++\ldots \ldots . . .(1)$

In equation 1 , P represents the probability of participation in agricultural activities and (1-P) represents the probability of non-participation.

$P$ represents the predicted probability of the event which is coded with 0 (participation in agricultural activities) rather than with 1 (nonparticipation).

1 - P represents the predicted probability of non-participation and $\mathrm{X}$ represents predictor variables.

$\beta$ represents the slope parameters of the model, which measures the change in Infor a unit change in the explanatory variables. Table 1 illustrates the variables that were used in the study and their expected signs.

\section{RESULTS AND DISCUSSION}

Of the 140 participants, forty-eight percent were female, and fifty-two percent were male. This finding is consistent with Torimiro and Oluborode (2006) who discovered males usually dominate in rural areas because of farming oc- 
Table 1: Variables for the binary the model

\begin{tabular}{|c|c|c|c|}
\hline Variable & Description of variables & Measure & $\begin{array}{l}\text { Expected } \\
\text { sign }\end{array}$ \\
\hline \multicolumn{4}{|c|}{ Dependent Variable } \\
\hline Part & Participation in agricultural activities & $\begin{array}{l}\text { Dichotomous } \\
\text { (0 if yes: } 1 \text { if no) }\end{array}$ & \\
\hline \multicolumn{4}{|c|}{ Explanatory Variables } \\
\hline Gender & Gender of respondents & $0=$ female $; 1=$ male & $-/+$ \\
\hline Youth Prog & Youth programmes availability & Dummy & $-/+$ \\
\hline Involve Ben & $\begin{array}{l}\text { Benefits for involvement in agriculture } \\
\text { programmes }\end{array}$ & Dummy & $-/+$ \\
\hline Employment & If whether the participant is employed & Dummy & $-/+$ \\
\hline Resource & If whether they are agricultural resources & Dummy & $-/+$ \\
\hline Prog Avail & $\begin{array}{l}\text { If whether they are agricultural programmes } \\
\text { available }\end{array}$ & Dummy & + \\
\hline
\end{tabular}

cupations. Similarly, Cheteni (2014) noted that male-headed household dominated in the Eastern Cape Province. Table 2 shows that thirty percent respondents were within the age range of 32-35 years, almost thirty-five percent were within the age group 23-31 years , and thirtyfive percent within 15-22 years. Most respondents had secondary education (73 \%) and sixty percent were temporary employed. The findings

Table 2: Demographic of the respondents

\begin{tabular}{lc}
\hline Variables & Percentage \\
\hline Gender & \\
Male & 52 \\
Female & 48 \\
Age & \\
15-18 & 15 \\
$19-22$ & 20 \\
$23-31$ & 35 \\
32-35 & 30 \\
Education Level & \\
No education & 5 \\
Primary & 10 \\
Secondary & 72.5 \\
Tertiary & 12.5 \\
Employment Status & 60 \\
Temporary & 25 \\
Self-employed & 2.5 \\
Permanently employed & 12.5 \\
Other forms of employment & \\
Participation in Agricultural Programmes & 40 \\
Yes & 60 \\
No & \\
Marital Status & 67.5 \\
Single & 25 \\
Married & 5 \\
Divorced & \\
Widowed & \\
\hline
\end{tabular}

are consistent with Cheteni (2014), who found that a number of youth possessed at least a secondary qualification in the Eastern Cape. At least sixty percent were not participating in any agricultural programme and sixty-eight percent of participants were single. The implication of this finding is that the majority of the respondents were literate, hence, literacy is expected to influence their perceptions of information received and utilized for agricultural activities, as well as, their decision to migrate to urban areas. Furthermore, educated people are expected to accept a moderate degree of awareness about agricultural activities. Jibowo and Sotomi (1996) noted that the youth have a greater knowledge acquisition propensity, therefore, they are eager to discover new ideas or inventions.

The respondents were asked about their sources of income. A total of sixty percent relied on social grants for their livelihoods. The percentage of people relying on social grants is reflective of the challenges faced by many youth in the Eastern Cape Province. The province has the largest number of unemployed youth (DAFF 2013). Respondents who were formally employed were thirteen percent. The labour market mainly in agriculture is said to have a pool of unskilled workers, this has led to casualization and wage declines (Agri SETA 2010). Hence, many people are discouraged from participating in agriculture due to low wages.

In order to understand the challenges faced by the youth, a question was posed on which programmes they knew. A total of fifty percent knew cattle farming programmes, eighteen per- 
cent knew dairy farming, thirteen percent knew beef farming, thirteen percent knew crop production and three percent knew poultry. It can be deduced from the findings that most respondents knew livestock programmes with the exception of the thirteen percent who knew crop production. When asked which programmes they prefer, most youth stated that they are into livestock programmes. However, Gwary et al.'s (2008) study reported that youth were more interested in crop production than livestock because of the short gestation period of crop varieties produced which ensured quick income. Furthermore, youth shunned livestock production because of intensive capital requirements. The findings in this study directly contradict Gwary et al. (2008). Therefore, it can be concluded that factors influencing youth to participate in farming are diverse.

The respondents were further asked what benefits they would get from their involvement in agriculture. A total of thirty-three percent respondents believed that they will be self-employed because agriculture gives them an opportunity to be entrepreneurs. A total of eighteen percent stated that they will benefit with money since they can sell agriculture products to people, fifteen percent believed that participation will lead to a permanent job, thirteen percent were of the position that agriculture will alleviate poverty in their families. The respondents were given a question asking about their interests in farming. A total of fifty-eight percent had no interest in farming, twenty-five percent had a fair interest and only thirteen percent had more interest in farming. The findings of the survey revealed that youth perceive agriculture as a bad career. Furthermore, views received from the respondents were that it is hard for them to be in farms yet their siblings are working in big cities. One of the reason was that agriculture is a physical job, as a result, a number of youth were not keen on working hard to get income. Moreover, some respondents said that whenever they think of agriculture they associate it with sewage smell. This shows a negative perception held by youth on agricultural activities.

A three-way cross tabulation was done in order to understand if gender had an influence in the participation in agricultural activities and involvement in farming. Among males who were involved in farming a total of fifty percent had interest towards agriculture. Yet, among males who were not involved in farming a total of forty percent had no interest towards agriculture. Similarly, there were fifty percent females involved in farming who had an interest towards agriculture, and forty-three percent of the females not involved in farming had no interest towards agriculture. The results are shown in Table 3.

It can be concluded that females who were not involved in farming had a higher percentage of people who were not interested in agriculture compared to males, the number of females who were involved in farming and had an interest towards agriculture was overall at 66.7 percent $(50+16.7)$ compared to males fifty percent. Therefore, more females who were involved in farming had a better interest and perception towards agriculture compared to males. Musemwa et al. (2007) had similar findings with regard to youth in Eastern Cape, the study stated that most youth view agriculture as a dirty job. Hence, this was a cause of concern as most young people were shunning agricultural activities. The findings are similar to Abdullah (2013) who found that attitude towards agriculture has a significant influence on youth interest in agriculture. Similarly, Waldie (2001) is of the opinion that as long as agriculture is seen as inferior,

Table 3: Cross tabulation on farming involvement

\begin{tabular}{|c|c|c|c|c|c|c|c|c|}
\hline \multicolumn{9}{|c|}{ Cross tabulation } \\
\hline \multicolumn{9}{|c|}{ Interest towards agriculture } \\
\hline Gender & & & & $\begin{array}{c}\text { No } \\
\text { interest }\end{array}$ & $\begin{array}{l}\text { Less } \\
\text { inter- } \\
\text { ested }\end{array}$ & Neutral & $\begin{array}{l}\text { Intere- } \\
\text { sted }\end{array}$ & $\begin{array}{l}\text { More } \\
\text { inter- } \\
\text { ested }\end{array}$ \\
\hline \multirow[t]{2}{*}{ Male } & Involved in & Yes & $\%$ within involved in farming & 20 & 0 & 30 & 50 & 0 \\
\hline & farming & No & \% within involved in farming & 40 & 20 & 0 & 30 & 10 \\
\hline \multirow[t]{2}{*}{ Female } & Involved in & Yes & $\%$ within involved in farming & 16.7 & 0 & 16.7 & 50 & 16.7 \\
\hline & farming & No & \% within involved in farming & 42.9 & 14.3 & 14.3 & 21.4 & 7.1 \\
\hline \multirow[t]{2}{*}{ Total } & Involved in & Yes & $\%$ within involved in farming & 18.8 & 0 & 25 & 50 & 6.3 \\
\hline & farming & No & $\%$ within involved in farming & 41.7 & 16.7 & 8.3 & 25 & 8.3 \\
\hline
\end{tabular}


youth will seek whatever seems good to them in non-agricultural sectors in the cities. This lack of interest in agriculture has contributed to young people migrating to cities in search of employment opportunities. This was further confirmed by the Chi-square test in Table 4 . The Pearson Chi-square statistics is 9.618 and the p-value is < 0.05 , thus the null hypothesis that the table variables are independent can be rejected. Thus, we can conclude that there is a significant association between involvement in farming and interest towards agriculture. However, the chi-square does not give us any information how the variables are related or how strong the relationship is.

\section{Binary Model Results}

A binary logistic regression analysis was conducted to predict youth who were involved in agricultural activities using gender, employment status, youth programmes, agricultural resources available, programme available as predictors. A test of the full model against a constant only model was statistically signiûcant, indicating that the predictors as a set reliably distinguished between participants in agricultural activities and non-participants (Chi-square $=21.363, p<.002$ with $\mathrm{df}=6$ ). Nagelkerke's $\mathrm{R}^{2}$ of .559 indicated a moderately strong relationship between prediction and grouping. Prediction success overall was seventy-five percent (79.2\% for No and $68.8 \%$ for Yes). The Wald criterion demonstrated that Youth Programme, Resource, Programme Availability made a significant contribution to prediction ( $\mathrm{p}=.013)$. Gender, Employment and Benefits were not significant predictors. $\operatorname{EXP}(B)$ value indicates that when Youth Programmes are increased by one unit (one programme) the odds ratio is 8 times as large and therefore youth are 8 more times likely to take the offer of participating in agriculture programmes. Also, when Resources are raised by one unit the odds ratio is 9 times as large and therefore youth are 9 times likely to participate in agriculture when resources are increased. Lastly, when Programmes available are increased by a unit the odds ratio is 18 times and therefore youth are like to participate in agricultural activities when they are more programmes available for agriculture. Table 5 shows the model results. The results of the binary model are consistent with Mangal (2009) who pointed that there is a lack of youth participation in agriculture. The United Nations (2011) supports this observation, but it points that there is a lack of willingness of youth participation in agriculture. Thus, supporting the study findings that youth par-

Table 4: Chi-square tests

\begin{tabular}{llccc}
\hline Gender & & Value & df & Asymp. Sig. (2-sided) \\
\hline \multirow{2}{*}{ Male } & Pearson Chi-square & $9.057^{\mathrm{b}}$ & 4 & \\
& Likelihood ratio & 11.534 & 4 & $.060^{*}$ \\
\multirow{2}{*}{ Female } & Linear-by-linear association & 2.377 & 1 & $.021^{* *}$ \\
& Pearson Chi-square & $3.220^{\mathrm{c}}$ & 4 & .123 \\
\multirow{2}{*}{ Total } & Likelihood ratio & 3.784 & 4 & .522 \\
& Linear-by-Linear association & 2.470 & 1 & .436 \\
& Pearson Chi-square & $9.618^{\mathrm{a}}$ & 4 & .116 \\
& Likelihood ratio & 11.184 & 4 & $.047^{* *}$ \\
& Linear-by-linear association & 4.974 & 1 & $.025^{* *}$ \\
\hline
\end{tabular}

Note: ${ }^{* * *}$ Significant at $1 \%$ level; ${ }^{* *}$ Significant at $5 \%$ level; ${ }^{*}$ Significant at $10 \%$ level.

Table 5: Binary model results

\begin{tabular}{|c|c|c|c|c|c|c|}
\hline Variables & $B$ & S.E. & Wald & $d f$ & Sig. & $\operatorname{Exp}(B)$ \\
\hline Gender & 1.282 & 1.039 & 1.523 & 1 & .217 & 3.605 \\
\hline Empl & .763 & .965 & .626 & 1 & .429 & 2.146 \\
\hline Youth Prog & 2.121 & 1.112 & 3.638 & 1 & $.056^{* *}$ & 8.341 \\
\hline Involve Ben & -1.062 & 1.212 & .768 & 1 & .381 & .346 \\
\hline Resource & 2.204 & 1.238 & 3.170 & 1 & $.075^{* *}$ & 9.059 \\
\hline Prog Avail & 2.912 & 1.237 & 5.544 & 1 & $.019^{* * *}$ & 18.401 \\
\hline Constant & -3.438 & 1.814 & 3.590 & 1 & $.058^{* *}$ & .032 \\
\hline
\end{tabular}

Note: ${ }^{* * *}$ Significant at $1 \%$ level; ${ }^{* *}$ Significant at $5 \%$ level; ${ }^{*}$ Significant at $10 \%$ level. 
ticipation in agriculture is a major problem. However, the study did not find any link between employment and participation in agriculture as pointed by Ommani (2006).

\section{CONCLUSION}

Based on the descriptive results from the study, it can be concluded that youth have a negative perception on agriculture. The findings from the survey highlighted that youth are not participating in farming as highlighted by a number of research articles in South Africa. Many young people still view agriculture as working in farms physical. Furthermore, a number of incentives are needed to convince youths that agriculture can provide a good career. More so, even though agriculture is taught in secondary schools it can be ascertained that most young people would rather go into different career paths when in tertiary because of the perceptions attached to agriculture. The binary model showed that programmes available, resources and programme involvement had a significant effect in influencing youth participation in agricultural activities. Moreover, this in turn explained the current trend in youth involvement in agriculture especially in the Eastern Cape Province.

\section{RECOMMENDATIONS}

Based on the study it is recommended that future agricultural programmes for youth should include hands-on activities designed to increase knowledge of basic agriculture-related concepts. According to the survey conducted, a number of youth migrate to urban areas in search of jobs. So teaching urban agriculture may offer one of the untapped avenues in youth empowerment. A number of youth programmes in agriculture can be improved by offering in- school visits for those youth studying and follow up materials. It should be noted that not every youth wants to learn about agriculture, but, in areas that are more rural it may be necessary to create that interest in order to improve their participation. Furthermore, if the South African government wants to involve more youth into agriculture it is imperative that they start engaging with the communities where the youth stay. The survey showed that most youth are from families that do subsistence farming. Therefore, involving communities maybe a recipe for success in improving youth participation in agriculture programmes. In a nutshell, the study provided insight into understanding youth perception and participation in agriculture and it adds to a body of knowledge in research related to agriculture perception and participation.

\section{REFERENCES}

AgriSETA 2010. Sector Analysis Agriculture. Draft Paper. Pretoria: South Africa.

Anania P, Kimaro P 2016. Factors affecting effective youths' participation in agricultural marketing cooperatives in Tanzania. International Journal of Economics, Commerce and Management, 3(2): 709-730.

Cheteni P 2014. Barriers and Incentives to Potential Adoption of Biofuel Crops by Smallholder Farmers in Selected Areas in the Chris Hani and O.R Tambo District Municipalities, South Africa. Master Thesis, Unpublished. Alice: University of Fort Hare.

Department of Agriculture Forestry and Fisheries (DAFF) 2012. Agricultural Statistics. From <http:// www.nda.agric.za/docs/statsinfo/Ab2012.pdf $>$ (Retrieved on 11 December 2015).

Department of Agriculture Forestry and Fisheries (DAFF) 2013. Quarterly Economic Overview of the Agriculture, Forestry and Fisheries Sector. From <http://www.nda.agric.za/docs/Economic_analysis/ Q_AFF07-092011_.pdf> (Retrieved on 12 May 2015).

Department of Agriculture Forestry and Fisheries (DAFF) 2014. Quarterly Economic Overview of the Agriculture, Forestry and Fisheries Sector. From <http://www.nda.agric.za/docs/Economic_analysis/ Q_AFF07-092012.pdf> (Retrieved on 12 May 2015).

Food and Agricultural Organisation (FAO) 2011. Rural Youth Situation, Needs and Prospects - An Overview with Special Emphasis on Africa - Part I: Current Situation and Needs of Rural Youth From <http:/ /www.fao.org/docrep/x5636e/x5636e01.htm> (Retrieved on 10 June 2014).

Ghadiri M 2005. Effective Factors of Rural Youth Attitude in Employment in to Agricultural Activities. MS Thesis, Department of Rural Development, Science and Research. Tehran: University of Iran.

Gwary MM, Pur JT, Bawa JB 2008. Socio-economic determinants of youths' involvement in agricultural activities in Askira/Uba Local Government Area of Borno State. In: AA. Ladele (Ed.): Policy Advocacy Role in Agricultural and Rural Transformation in Nigeria. Proceedings, $17^{\text {th }}$ Annual Congress of the Nigerian Rural Sociological Association (NRSA), NRCRI, Umudike, 19-22 August, pp. 1523.

Jibowo AA, Sotomi AO 1996. The youths in sustainable rural development: A study of youth programmes in Odeda Local Government Area of Ogun State. In: AA Ladele (Eds.): Policy Advocacy Role in Agricultural and Rural Transformation in Nigeria. Proceedings, $17^{\text {th }}$ Annual Congress of the Nigerian Rural Sociological Association (NRSA), NRCRI, Umudike, 19-22 August, pp. 54-57. 
Kimaro PJ, Towo NN, Moshi BH 2015. Determinnats of rural youth's in agricultural activities: The case of Kahe East Ward in Moshi Rural District, Tanzania. International Journal of Economics, Commerce and Management, 3(2): 1-47.

Musemwa LC., Chagwiza C, Sikuka W, Fraser G, Chimonyo M, Mzileni N 2007. Analysis of cattle marketing channels used by small scale farmers in the Eastern Cape Province, South Africa. Livestock Research Rural Development, 19: 131.

Nnadi FN, Akwiwu CD 2008. Determinants of youths' participation in rural agriculture in Imo Staette, Nigeria. Journal of Applied Sciences, 8(2): 328-333.

Ommani AR 2006. Job creation for rural youth. Dehati Journal, 3(29): 41-46.

Outley C 2008. Perceptions of agriculture and natural resource careers among minority students in a national organization. In: DJ Chavez, PL Winter, JD Absher (Eds.): Recreation Visitor Research: Studies of Diversity. Gen. Tech. Rep. PSW-GTR-210. Albany: United States of America.

Russell EB 2001. Attracting Youths to Agriculture. University of Illinois: Urbana Champaign.

Samardick R 2000. Youth Employment in Agriculture. From <http://www.bls.gov/opub/rylf/pdf/chapter5. pdf $>$ (Retrieved on 5 May 2015).

Statistics South Africa 2011. Census 2011 Municipal Report Eastern Cape Report No. 03-01-50. Pretoria: South Africa.

Statistics South Africa 2012. Agricultural Statistics 2012. From <http://www.nda.agric.za/docs/statsinfo/Ab2012.pdf $>$ (Retrieved on 4 June 2015).
TeLintelo D 2001. Youth and Policy Processes. Future Agricultures. From <www.future-agricultures.org> (Retrieved on 26 July 2015).

Torimiro E, Oluborode A 2006. Exploring socio-economic correlates of production needs for Southwest Nigeria. Journal of Applied Science, 5: 248-255.

Tregurtha N, Vink N 2008. Review of Agricultural Policies and Support Instruments 1994-2007. Presidency Fifteen Year Review Project. Pretoria: South Africa.

United Nation 1999. Youth Policy Formulation Manual. New York: United Nations.

United Nations (UN) 2012. International Cooperative Youth Statement in 2012. Presented at the United Nations during the Closing Ceremonies of the International Year of Cooperatives, November 2012. Geneva, Switzerland.

Waldie K 2001. Youth and rural livelihoods. LEISA, 20(2): 1-20. Reading: United Kingdom.

Woolard I 2013. The Youth Unemployment Problem in South Africa within the International Context. Saldru, University of Cape Town. From <http://www. econ3x3.org/article/how-old-age-pension-helpingyoung-people-rural-areas-find-jobs\#sthash. nrn XSX8n.dpuf $>$ (Retrieved on 2 October 2015).

World Wildlife Fund 2008. Agriculture and Biodiversity Initiative. From <http://www.worldwildlife.org/ cci/agriculture.cfm> (Retrieved on 7 June 2015).

Paper received for publication on July 2015

Paper accepted for publication on August 2016 